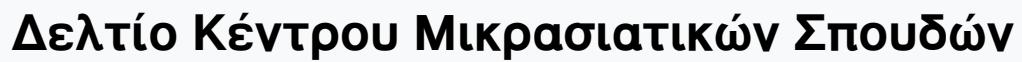

Tóp. 16 (2009)

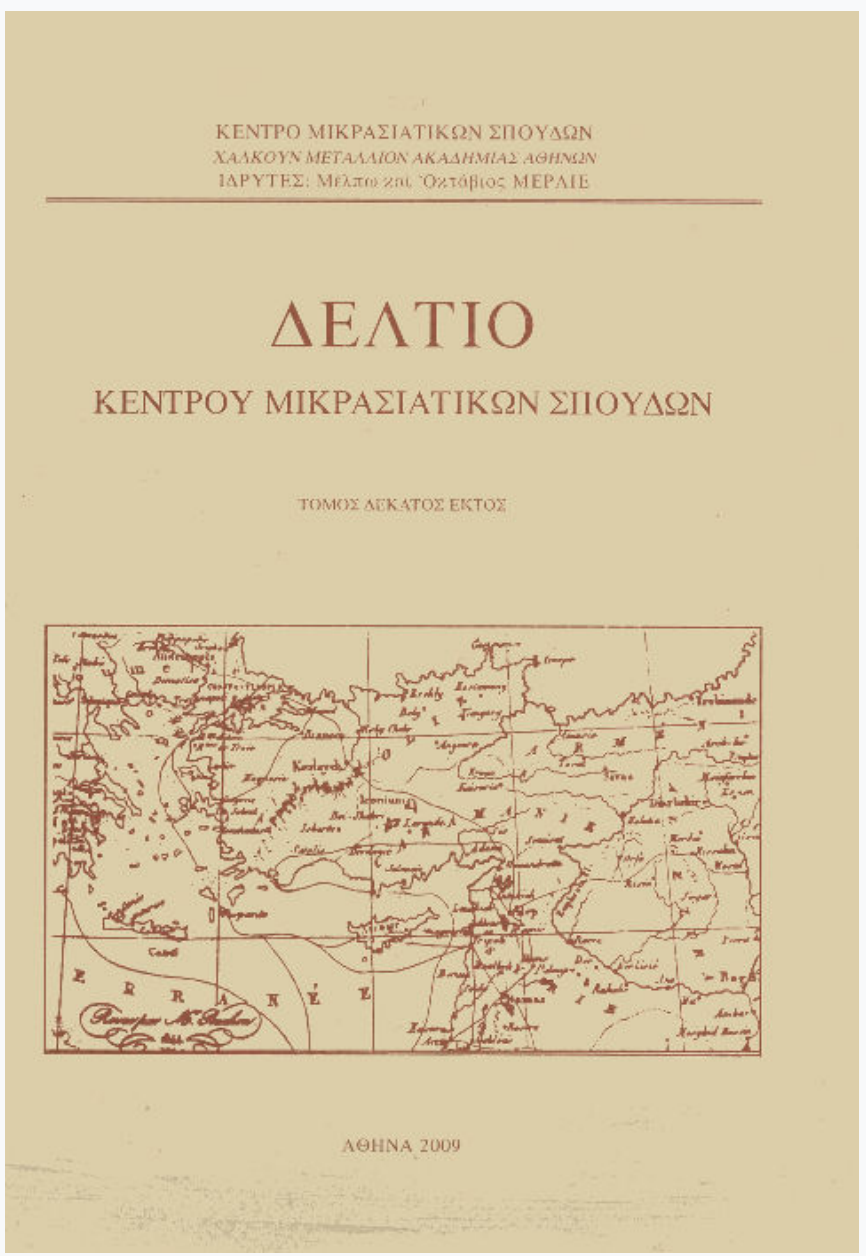

\section{Aristotle, loannes Gennadios, and the idea of a scholarly library}

\section{G. L. Huxley}

doi: $10.12681 /$ deltiokms.21

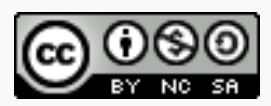

Aঠ¿ıı Xpńбnৎ Creative Commons Attribution-NonCommercial-ShareAlike 4.0.

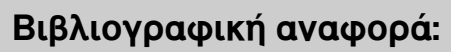

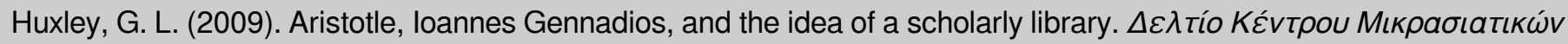

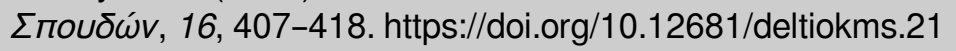


MAPTYPIE $\Sigma$ 



\section{G. L. HUXLEY}

\section{ARISTOTLE, IOANNES GENNADIOS, AND THE IDEA OF A SCHOLARLY LIBRARY*}

We are gathered here in this fine lecture-hall to venerate the memory and to celebrate the munificence of Ioannes Gennadios. He is the founding

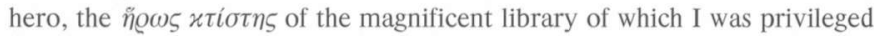
to have been the Director for three years from 1986 onwards. When the Friends of the Library honoured me with the invitation to speak this evening, I welcomed the opportunity to praise Gennadios and to think about the character and purposes of scholarly libraries, of which the Gennadeion is pre-eminent example, in the promotion of understanding and civility. What are the aims of such a library and what are we doing when we study in one?

The questions are philosophical and they are of a kind inviting recourse to Aristotle. In a long life, from undergraduate days onwards, I have found that seeing what Aristotle has to say about a topic is almost invariably helpful. Often there is no need to look beyond the Stagirite. But first let us think of Ioannes Gennadios himself. His presence in the Library is strong; I felt it every day. With calm dignity he looks out from his portraits and with confidence he engages the eye of the camera. He died in the year of my birth; yet I became aware that he was presiding still over our undertakings. His love of books and his skills as a diplomatist gave his character a serenity. He was proud, but not with the pride that cometh before a fall. In many respects this distinguished Hellene, who was at home in the life of

* A lecture given in the Cotsen Hall of the American School of Classical Studies at Athens on 26 March 2009. 
London high society, resembled the Aristotelian $\mu \varepsilon \gamma \alpha \lambda \delta \psi v v \chi \circ$, the proud man of great soul. The proud man, Aristotle tells us in the Nicomachean Ethics (5.3), thinks himself worthy of great things and he claims what is befitting to his merits. He seeks honour according to his deserts, and he is thoroughly deserving because he is good. The $\mu \varepsilon \gamma \alpha \lambda o ́ \psi v \chi 05$ is concerned with honours, but he will act with moderation in good or evil fortune, whatever may befall him. Gennadios experienced political setback - notably from the government of Mr Tricoupis, yet he bore himself with dignity; and there were honours in abundance, in Greece, in Britain, and internationally. Aristotle admits that the $\mu \varepsilon \gamma \alpha \lambda \dot{\alpha} \psi v \chi o \varsigma$ can be deemed to be disdainful, and indeed there was a certain disdain in Ioannes towards those who had thwarted him.

No man is an island, and Ioannes recognised that he owed much to the example of his father George, a renowned champion of Greek Independence, who died when Ioannes was ten. Let us remember that the Gennadios Library is named in honour of the father, not of the son. Aptly the opening ceremony was held on St George's Day in 1926, April 23rd. Let us remember also the wife of Ioannes, Florence, who took the Greek name Anthe. She was a person of intellectual distinction whose merits were drawn to my attention by my wife Davina in the autumn of 1986 . Florence was a painter, so good a painter that some of her work was exhibited at the Royal Academy and in other galleries in London. Her father Samuel Laing was also a person of quality. He was a Wrangler at Cambridge, a politician, an adviser to the Government of India, and a writer upon philosophical subjects. He also was Chairman of a major railway company. In short, he was a fine example of the intellectual aristocracy of the Victorian age. His daughter Florence was a widow when she met and married Ioannes; at the wedding he was already fifty-eight years old. Theirs was a true meeting of minds. She was independently rich, and she knew that she could share her new husband's devotion to Greece and to Hellenism. As Donald M. Nicol has written, "[...] she knew that she could not love Ioannes Gennadios without also loving Greece, its past, present and future. She made it her business to do both until his dying day" '. It is no accident that bookplates of their books in the Library name both Ioannes and Anthe. Lack of money had

1. Ioannes Gennadios - The Man. A biographical Sketch, American School of Classical Studies at Athens, 1990, p. 16. 
forced him to sell many of his books, and the long task of rebuilding his collection began on their honeymoon; she bought back for him some volumes he had earlier been compelled to sell. I was delighted when more Laing papers were added to the archives by Mrs Joan Stubbings (née Laing), wife of Dr F. H. Stubbings of Emmanuel College, Cambridge, Dr Stubbings and I had been fellow excavators at Mycenae in the early 1950s under Professor Alan Wace.

Let us also remember the wisdom of the American School of Classical Studies at Athens. The first approach to Ioannes Gennadios seems to have been made in Washington, D.C., by Professor Mitchell Carroll of George Washington University. The suggestion that the entire collection of books should go to the School at Athens was readily taken up by Professor Edward Capps of the School's Committee of Management. Money was found for a specially constructed building through the generosity of the Carnegie Corporation; Gennadios himself had insisted upon a separate structure. It was through the efforts of Professor Bert Hodge Hill of the School that in 1922 with signal generosity the Greek Parliament assigned land expropriated from Mone Petraki in perpetuity to the Trustees of the American School. It is a remarkable fact that the legal arrangements were expeditiously completed at the time of catastrophic events in Asia Minor. Ioannes Gennadios wisely insisted in his Deed of Gift that his books should never leave the building.

The prime purpose of a scholarly library is to permit those who desire to learn, to pursue knowledge for its own sake. To study for the sake of knowledge is increasingly rare in our crass world of utilitarian applicability; but Aristotle understood that the highest tasks for the human intellect are contemplative. He insists that the life of money-making is not the highest good (N.E. 1.5) because it is undertaken under compulsion; it cannot be true happiness. Perfect happiness comes from contemplation, and contemplation is closely connected with the divine in us (N.E. 10.7). Aristotle is here arguing for $\theta \varepsilon \omega \varrho i \alpha$ as the highest good and the purest of happiness.

It is, I think, difficult to imagine a closer approach to Aristotelian $\theta \varepsilon \omega \varrho i \alpha$ than the reading and pondering of a serious work of scholarship or science in a library such as the Gennadeion. It is an activity near to prayer, and that perhaps is why Aristotle writes in this context about what is most divine in us. Philosophy has pleasures that are wondrous, he says, in their purity and lastingness and it is reasonable to suppose that those who know will experience greater pleasures than those who engage in inquiry alone. 


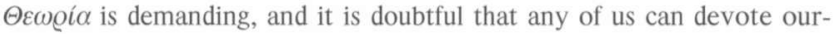
selves to it continuously (although Aristotle seems to think that some persons might do so). In libraries there are, however, blessings, such as occur, in Aristotelian words, $\varkappa \alpha \tau \dot{\alpha} \sigma v \mu \beta \varepsilon \beta \eta \varkappa o ́ \zeta$, accidentally. One such blessing is the chance find made in browsing on the open shelves or in the stacks. Let us consider some instances.

Recently I received a letter from George D'Almeida, who is both poet and painter. In it he mentioned a discovery made when he was reading a Greek lexicon in the Yale University Library. The lexicon had been donated by Cole Porter, the lyrical musician famous for works including "Night and Day". It is clear that Porter had studied ancient Greek. This surely is a fact known to few, but it is pleasant to suppose that discipline in Greek had contributed to the neatness of Porter's creativity.

Another example comes from the Gennadeion itself. One day I happened upon a text written in Latin. It is a manuscript letter of the great German scholar of ancient Greek, Gottfried Hermann, sent to the Regius Professor of Greek at Oxford Thomas Gaisford. Their correspondence was rare: indeed I know of no other exchange between them. The one scholar knew little or no English, the other little or no German. Latin was a natural language of scholarly communication in their time as it had been for centuries. Transcription was in parts difficult, but I sent a first attempt to Professor W. M. Calder in the United States. He is a leading historian of nineteenth century German classical studies. In due course the text was published with a commentary in the periodical Philologus [142 (1998.2) 359-360]. Perhaps the best word to describe such happy accidents is serendipity.

One day not long after we had left the Gennadeion, I happened to be in the small town of Much Wenlock in Shropshire, an English county beside the Welsh border. There in the local museum was, to my astonishment, a letter written by Ioannes Gennadios from the Greek Legation in London. The recipient was Dr William Penny Brooks and the year was 1877. The reason for the correspondence was celebration of local Olympic games in Shropshire. For the games King George I of Greece sent an inscribed silver cup. There was also a Wenlock prize sponsored by Penny Brooks and presented at the games instituted in Athens by Evangelos Zappas. Baron de Coubertin, who is accounted founder of the modern international Olympics, visited Brooks in Much Wenlock in 1890. The background to these events is lucidly described by Sir Michael Llewellyn-Smith in his book 
Olympics in Athens 1896 (London 2004). It is clear that Ioannes Gennadios has a place in any account of the origins of the modern Olympics.

When I returned to Ireland from working in Greece in 1989, I used to study much in the Library of the Royal Irish Academy in Dublin. The Academy, perhaps with my experience gained at the Gennadeion in mind, made me for a few years their Honorary Librarian. Here were endless opportunities for exploration in dusty shelves. A chance discovery was an inscription in a large volume stating that the book was a gift of the Princess Dashkova to the Academy. The Princess, by birth a Vorontsov, was one of the conspirators who ensured that Catherine the Great became Empress of the Russias. The book was given during a visit of the Princess to Ireland. No less interesting was the book itself. It was a translation into Greek of Virgil's Georgics. The translator was the learned Greek ecclesiastic Eugenios Voulgaris, who was closely associated with the ambitious Greek Project of Catherine's minister Potemkin. The translation was sponsored by Potemkin and the work, according to the title pages in Greek and Latin, was intended for the use of the Graeco-Russian youth. Thus the book was part of the educational project in Russia intended to train Greeks for a civil service to be set up in conquered parts of the Ottoman Empire. The ultimate aim of the Project was to enthrone Catherine's grandson Constantine at Constantinople. The purpose seems lacking in realism now, but it was seriously undertaken by the authorities, ecclesiastical, military, and political, of the time in Saint Petersburg.

The Greek project is relevant to the concerns of Gennadios, the diplomatic collector of books. He took a deep interest in Greek and Orthodox influences upon the Slavonic world, so deep indeed that I was moved to write a short monograph with the title "East Rome and the Evangelization of Russia. A Lecture on some Byzantinoslavica in the Gennadius Library ....". The purpose was to draw attention to the valuable holdings of interest to historians and philologists concerned with Russia and adjacent Slavonic territories and the Balkans. Gennadius, whose thinking was Panhellenic and embraced not only Byzance après Byzance but also Byzance au delà de Byzance, would be pleased to know that Slavica in the Library have been steadily augmented over the years. One addition comes to mind from the years 1986 to 1989 . It was clear to me that Gennadios had a profound knowledge of Balkan affairs. His understanding had been recognised, for example, by the award of the title Grand Officer of the Danilo from the government of Montenegro. He carried a Serbian title, too. With his 
Balkan interests in mind, I wanted to increase our holdings in Old Church Slavonic. The Bulgarian Embassy to Greece became aware of my intention and with prompt generosity presented a copy of a fine reproduction in colour of a Glagolitic manuscript, Codex Assemanius Vaticanus 3. Later the - then Communist - Bulgarian authorities invited me as Director of the Gennadeion to the inauguration of the Dujćev Centre for Byzantine Studies and took me to see in the monastery of Saint Nikolaos near Mâgliž a fresco showing Saints Kyril and Methodios together with Saint Patrick, patron saint of Ireland. The fresco had been painted in 1909 at the cost of the Irish champion of Bulgarian independence Pierce O'Mahony. The Irish connection there was of great interest to me, since much of my life has been devoted to the promotion of ancient Hellenic and Byzantine studies in Ireland. Philhellenism, let us remember, has long been vigorous in Ireland. A leading champion of Greek independence was Sir Richard Church, a warrior who became a Greek-citizen. He was a native of Cork in Ireland. It was Ioannes Gennadios who delivered the funeral oration in honour of Church in April 1873; Church had been a friend of George Gennadios. Thinking of the Irish Philhellenes, I was able, through the good offices of the Embassy of Ireland, to set up an exhibition in the Library. The title was "Ireland and the Hellenic Tradition" and it was timely, because both Greece and Ireland were joining the European Union. Gennadios said of Sir Richard Church that he was "the truest Hellene, the most steadfast and the most affectionate of the sons of Greece" .

One of the greatest strengths of the Gennadius Library is the collection of writings on travel in Greece, the Balkans, Asia Minor, and the Levant. Many of the books describe places and landscapes that have been transformed, not invariably for the better, by growth of populations, by industry, and by development. Topographers can learn much from the books of travellers, and I urged, with the support of Professor John Camp, students of the School to come to the Gennadeion to study such works before they went on the School's excursions. The holdings relating to the Ionian isles and to the Troad are conspicuously strong. They prompted me to write a monograph entitled Homer and the Travellers. A Lecture on some anti-

2. See Patrick Comerford, "Sir Richard Church and the Irish Philhellenes", in The Lure of Greece, J. V. Luce, C. Morris, C. Souyoudzoglou-Haywood (eds), Dublin 2007, p. 11. 
quarian and topographical Books in the Gennadius Library. Prominent in the Ionian section is Kephallenia or Cephalonia, and in the history of modern Cephalonia an outstanding personage is the Irish-born Charles Napier, who with his Irish colleague Lieutenant Kennedy, designed a system of roads for the island. Napier loved the islanders; he wrote: "The merry Greeks are worth all other nations put together. I like to hear them; I like their fun, their good humour, their Paddy ways, for they are very like Irishmen". I cannot go here into a currently fashionable theory according to which the island Thiáke- -Itháke is not Homeric Ithaca, but most of the early travellers to the Ionian isles would have been appalled by the hypothesis, as indeed I am.

Mention of the Troad reminds us of Schliemann. We are fortunate indeed to possess his papers, and good use has been made of them by topographers, and biographers, and historians of Homeric Scholarship. One may draw attention, if only by way of example, to the late David Turner's posthumously published study "Schliemann's Diary: Greece and the Troad, 1868 " in Volume 107 of the Annual of the British School at Athens. In our increasingly electronic world, where printouts are rare, and if they happen at all are vulnerable, and often ephemeral, documents - letters especially become irreplaceable testimonies to the past. That is why the archives of the Blegen and Gennadius Libraries, now being effectively co-ordinated by capable scholars led by Dr Natalia Vogeikoff-Brogan, deserve growing emphasis in the academic policies of the School. The recent donation of the Tsatsos papers has greatly strengthened the position of the archive as a treasure-house of the modern history of Greece. Serious scholars will be able to study through them not only political events but also legal, philosophical, and biographical topics, and the family's ties to the Seferiades family ensure that their correspondence will form a vital part of future histories of Greek literature, and especially poetry. The Library has fittingly expressed its gratitude to Mrs Mylona-Tsatsou, and the American School will be faithful in honouring the memory of Konstantinos Tsatsos and Ioanna Tsatsou.

The mention of the family of George Seferis (Seferiades) brings me to a central concern of all who study the historical continuity of Hellenism; he was born in 1900 in Smyrna, a city still then essentially Greek. Gennadios knew fully well that it is not possible to understand continuity if the Greeks of Anatolia are ignored; his books reflect the awareness, and being alert to the significance of Anatolian Hellenism, I endeavoured steadily to promote 
informal ties between the Gennadius Library and the Centre for Asia Minor Studies in the Plaka. The Centre was under the energetic direction of Professor Paschalis Kitromilides, whose contributions to the study of Hellenic continuity after 1453 have been consistently substantial - one thinks for example, of his work on Joseph Moisiodax and his intellectual ambience.

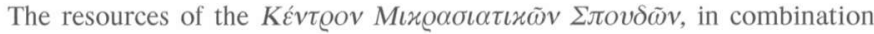
with the Anatolian collections in the Gennadeion, form a treasure of testimony deserving to be better understood by Hellenists. With continuity and social history present to mind, I welcomed a handsome gift of $K \alpha \varrho \alpha$ $\mu \alpha v \lambda i \delta \iota x \alpha$ into the Library; these books - in Turkish tongue and Greek script - were generously donated in 1989 by the Dalezios family of Kolonaki. Gennadios was interested in Karamanlidika; one item of his, a pamphlet on a game of fortune-telling, is neatly described by Leonora Navari in her catalogue of an exhibition celebrating in the year 2001 three-quarters of a century of the Library (p. 78).

Few Anatolian Greeks who were adults at the time of the Population Exchange are still with us. But I recall with a heartfelt sense of continuity a visit made to the Protopresbyter Theodoros Theodorides in 1986 in Peristeri. He had been brought up in Pharasa, a remote Orthodox Greek-speaking settlement in the south of Kappadokia; it lay near the Byzantine citadel of Rhodandos, built to guard a pass at what was for centuries a limit of East Roman power. Well into his ninth decade of life, Theodoros Theodorides was vigorous in health, clear in mind, and with an accurate memory. His work on the topography of Pharasa is acknowledged in the superb work of Friederich Rild and Marcell Restle, Kappadokien, published in the series Tabula Imperii Byzantini by the Austrian Academy of Sciences in 1981. I felt that I was hearing, perhaps for the last time, the authentic voice of continuity, of Byzantium after Byzantium, that had survived in a kleisoura beside the Onopniktes river in the Antitaurus mountains.

The high civility sometimes attained in Anatolian Hellenism is well illustrated in the writings of Elias Venezis. His book Alo $\iota \iota \dot{\eta} \Gamma \tilde{\eta}$ was drawn to my attention nearly four decades ago by our friend and a Friend of the Library, Aikaterine Kavvadia. Venezis is a vital witness to what was wrecked in 1922. In his distressful book Mikrasia, Chaire, now into its eighth edition (2005), he describes a visit of Monsieur Firmin Didot of the French publishing family, a Philhellene, to Kydonies or Kydonia in the Aeolis. The visit was made before the destruction in 1821, a burning from which the Greek mercantile community recovered before long. Venezis 
himself came from a family living at Kydonies. The Encyclopaedia Britannica of 1910 (1.448) describes Kydonies (Aivali) as "one of the most thriving towns of the Levant, with a purely Greek population distinguished for its commercial, industrial and maritime enterprise. The exports are olive oil, grain and wood, and a fleet of fishing boats supplies Constantinople and Smyrna with fish." Venezis recalls the description of the Academy at Kydonies given by Didot as it was before the conflagration of 1821 . The pupils staged the Hecuba of Euripides in ancient Greek and also the Per-

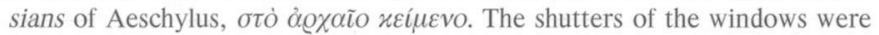
closed in order that the Turks would not see that the student-actors were bearing arms and would not think that an uprising was being prepared. The students in the Academy had voted for the following rule: that they must converse among themselves in ancient Greek, $\varepsilon \lambda \lambda \eta v \iota \sigma \tau i$. He who was unwilling to do so, must stand in front and as a penalty recite a page of Homer. Gennadius had hopes that Hellenism would continue to flourish within the Ottoman system as it was before 1914, and this awareness, together with diplomatic tact, ensured that he would accept an Ottoman honour; he became an Officer of the Nischan-i-Medjidi, and fittingly so, because his comprehensive Hellenism was never a narrow nationalism. He was a veritable Panhellene.

The Gennadius Library is a shared enterprise, and has been so since its inception. It is a roıvwvia. Aristotle has much to say about the role of Friends and Friendship in communal undertakings. Modern ethical philosophers, if they are concerned with friendship at all, usually think of friendships between individuals. But $\varphi \iota \lambda i \alpha$ in Aristotle is also communal. Friendly society in his Politics extends outwards from the household to the village; and the villages join together to form the society of the Polis. In an aside in the Nicomachean Ethics he remarks (8.9) that some communities come to be through pleasure, namely religious groups and social gatherings, the one for the purpose of sacrifice, the other for company. It seems to me that the Friends of the Gennadeion, who are both benefactors and enjoyers of the Library, come close to the Aristotelian concept of a roıvwví $\alpha$ founded upon $\varphi i \lambda i \alpha$.

The roıv They include the books, the Trustees, Officers, and members of the School; the special Trustees of the Gennadeion and its Director and Staff; the Friends, and the supporters in the Athenian community and beyond, including benefactors overseas. It is a noble enterprise, depending most of all 
upon the faithful beneficence of the American School for more than eight decades. Many have worked to ensure that the Library remains a beacon of Hellenism; let us remember in particular the devoted, scholarly direction given by Francis Walton. Charis Kalliga also deserves particular praise. I take the opportunity of thanking those who made happy my own years in the Directorship. I cannot name them all, but special gratitude is due to Mrs Sophie Papageorgiou, to Andreas Sideris, to Artemis Nicolaidou, Soula, and, last but not least, Vasso Rizou, who ensured that we worked in rooms both clean and comfortable. Under the guidance of its present energetic and prudent Director, I am confident, the Gennadius Library will continue to flourish and to make $\theta \varepsilon \omega \varrho i \alpha$ within its walls a daily reality.

If I am allowed a prayer, as though I were one of the old and time-worn priests in Aristotle's outline of an ideal city-state, it is that excessive reliance should not be placed upon electronic devices. Such equipment is vulnerable to climate change or civil disorder or power cuts or viral malignity or technical blunders. The use of the equipment is an example of what Aristotle calls $\tau \dot{\varepsilon} \chi v \eta$. A scholarly book is an instrument of $\dot{\varepsilon} \pi \sigma \tau \eta \dot{\mu} \mu \eta$, and the proponents of information-technology should be frequently reminded of the fact that information is not knowledge, and knowledge and understanding are not identical with theoretic wisdom, as Aristotle constantly emphasized. I therefore beg the authorities of the Gennadius and Blegen Libraries to keep the card catalogues up to date and not even to think about getting rid of them.

Civilisations are always fragile and vulnerable, and ours is no exception. The threat to Museums (consider what happened to the Museum in Bagdad six years ago), to art galleries, and to libraries is ever present. As we learn from relics of Aristotle's On Philosophy - an exoteric work now, alas, lost he was sharply alert to the possibility of wreckage and ruin in human society (Fr. 8 Ross). He wrote that humans were threatened with ruin from several causes, among them plague, starvation, earthquake, war, and various sicknesses. Aristotle, quoting Homer (Iliad 20. 215-218), recalled the tale of Dardanos who swam from Samothrace with fellow survivors of the cataclysm to settle on the foothills of Mount Ida, before Ilios was founded on the plain. Those who escaped feared at first to move down from the hills. Aristotle also remarked that proverbs are relics of ancient philosophy that had endured through the greatest ruins of mankind owing to their brevity and cleverness. 
Ours is a time of troubles - of potentially cataclysmic floods, of religiously driven terror, of vulnerable technologies, and of nuclear threat. What defences there can be of a treasure-house of civility such as the Gennadeion I do not know, but we should certainly be thinking of defences, if we are not to be left only with remembered proverbs.

There is, however, in addition, a less overt but more immediate threat; it is the threat to learning for its own sake, to $\dot{\varepsilon} \pi \iota \sigma \tau \eta \mu \eta$ and to theoretic wisdom founded upon knowledge. Not long ago a crassly utilitarian Minister of Education in a western European country dismissed mediaeval studies as "ornamental" and asked a scholar of Turkish philology why he was not doing something more useful. More recently in another European land a Minister of Education, proposing a "strategy" for universities, expressed the hope that opportunity for change (always assumed by politicians to be change for the better) would not be impeded by "closed ideological positions on important policy questions". His own position is, however, dangerously ideological since he assumed without hesitation that a university's sole purpose is to serve vital economic and social interests. It is agreed that universities can and should serve such interests, but their prime purpose is to preserve, to promote, and to increase knowledge for its own sake. Those politicians who ignore the prime purpose are barbarians within the gate. The citizens in Cavafy's poem "Waiting for the Barbarians" were tempted to think that the $\beta \alpha \dot{\alpha} \beta \alpha \varrho o \iota$ who, after all, never arrived, were some kind of solution: in Alan Boegehold's fine version:

"Because night came on and the barbarians did not come

And certain people have arrived from the border;

They say there are no more barbarians.

And now what will become of us without barbarians?

These people were in a way a solution.

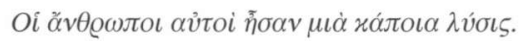

Let us never be tempted to concede that the soulless utility of today's neobarbarians let loose upon higher learning is any kind of solution. A scholarly library such as the Gennadeion is in the first line of defence against the temp-

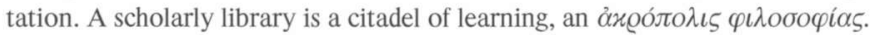
Lovers of knowledge must defend libraries. Let us be steadfast in rejecting technocratic enthusiasm for "bookless libraries". A bookless centre for information studies cannot be a true $\beta \iota \beta \lambda \iota 0 \theta \dot{\eta} x \eta$. 
Finally, to return to a question asked at the start.

What is the nature of the Gennadius Library? I have long believed that it is not simply a collection of fine books. It is a sanctuary of the Muses and it has its own founding hero, the son of George, husband of Florence, Ioannes Gennadios, great of Soul, the $\mu \varepsilon \gamma \alpha \lambda{ }^{\prime} \psi v \chi 0 \varsigma^{3}$.

3. I thank my friends Alan Boegehold, Carol Mattusch, and Richard Mason for helpful conversations from time to time over the years. 